\title{
Protein and Mineral Composition of Tepary Bean Seed
}

\author{
Harbans L. Bhardwaj ${ }^{1}$ and Anwar A. Hamama \\ Agricultural Research Station, Virginia State University, P.O. Box 9061, \\ Petersburg, VA 23806
}

\begin{abstract}
Tepary bean (Phaseolus acutifolius A. Gray), a native of southwestern U.S., is a promising plant for crop diversification and for production in short rotations with wheat. However, protein and mineral concentrations in tepary bean seed produced outside the southwestern U.S. are largely unknown. We evaluated concentrations of protein and various minerals in seed produced by eight tepary bean genotypes planted at three different dates each during 1997 and 1998 at Ettrick, Virginia. Significant year $\times$ planting date and year $\times$ genotype interactions existed for protein and other traits. Protein and zinc concentrations increased and calcium concentrations decreased with later plantings during both years. Mid-June planting had $14 \%$ higher protein concentration $(24.5 \%)$ than late-May planting $(21.4 \%)$ and mid-July planting had $6 \%$ higher protein concentration $(25.9 \%)$ than mid-June planting. Color of seedcoat was not associated with concentrations of protein or minerals. The average concentrations of boron, calcium, copper, iron, potassium, magnesium, manganese, phosphorus, sulfur, and zinc (mg/100g) were: 1, 184, 1, 11, 1531, 192, 3, 451, 311, 4 , respectively. Tepary bean seeds contained $24 \%$ protein as compared to reported average values of $22.3 \%$ in navy, $22.5 \%$ in red kidney, and $20.9 \%$ in pinto bean. The average iron concentration $(\mathbf{m g} / \mathbf{1 0 0 g})$ in tepary bean seed $(10.7)$ was higher than that in navy $(6.4)$, red kidney (6.7), and pinto (5.9) bean. Based on protein and mineral concentrations tepary bean seed compared well with seeds of navy, red kidney, or pinto bean.
\end{abstract}

American agriculture has traditionally relied upon a few crops, and a need exists for diversification of cropping system. Fletcher (2002) indicated that at least $67 \%$ of the increased value of crop production in Australia, over the period 1950 to 1992 , was derived from new crops. Blade and Slinkard (2002) cited the recent successful development of many new crops in Canada such as canola (Brassica campestris L. and B. napus L.), chickpea (Cicer arietinum L.), field pea (Pisum sativum L.), lentil (Lens culinaris Medik.), mustard (Brassica juncea L.), canaryseed (Phalaris canariensis L.), sunflower (Helianthus annuиs L.), and many spice crops that can be used to achieve crop diversification.

Previous research has indicated that tepary bean (Phaseolus acutifolius A. Gray) can be successfully produced in the mid-Atlantic region of U.S., potentially in rotation with wheat (Bhardwaj et al., 2002). Even though tepary bean is known to produce a nutritious seed that is suitable for human consumption (Nabhan, 1983; Scheerens et al., 1983), composition of tepary bean seed produced in the mid-Atlantic region of U.S. is not known. Given that full use of tepary bean as a food/feed crop cannot be realized without establishing its seed composition when produced in prospective areas, the

\footnotetext{
Received for publication 7 May 2003. Accepted for publication 9 Mar. 2004. Contribution of Virginia State University, Agricultural Research Station, journal article series 235 . The use of any trade names or vendors does not imply approval to the exclusion of other products or vendors that may also be suitable. We gratefully acknowledge the assistance of Jeffrey Brecht (University of Florida), LeRon Robbins (Louisiana State University), and anonymous reviewers for their valuable and helpful comments and suggestions.

${ }^{1}$ Corresponding author; e-mail hbhardwj@vsu.edu.
}

The soil type at the experimental location was Abel sandy loam (Fine Loamy mixed thermic Aquatic Hapludult). The weeds in these plots were controlled manually. All plots received one application of permethrin $(60 \mathrm{~g}$ a.i. per hectare of Ambush, Syngenta Crop Protection, Inc., Wilmington, DE 19897) and one application of lambda-cyhalothrin ( $20 \mathrm{~g}$ a.i. perhectare of Karate, Syngenta Crop Protection, Inc., Wilmington, DE 19897) insecticides.

At maturity, in early-October during both years, all plots (middle rows only during 1998) were harvested, and seeds from all replications of a genotype in each planting date experiment were bulked and chemically analyzed for concentration of protein and various minerals according to AOAC methods (1995) by A\&L Eastern Agricultural Laboratory, Richmond, Virginia. All data were analyzed by procedures in version 6.11 of SAS (SAS, 1996). The seed composition data were analyzed by using year $\times$ genotype $\times$ planting date mean squares as the error term (Steel and Torrie, 1980). Fisher's Protected LSD at 5\% level of significance was used for mean separation. The seed composition traits of tepary bean were compared to the average literature values for navy, red kidney, and pinto beans (USDA, 2002).

\section{Results and Discussion}

objectives of our studies were to characterize the protein and mineral composition of tepary bean seeds and to compare the composition of mature raw tepary bean seed to that of navy (Phaseolus vulgaris L.), red kidney (Phaseolus vulgaris L.), and pinto bean (Phaseolus vulgaris L.) based on values reported in the literature. Specifically, we evaluated protein and mineral composition in seeds of eight tepary bean genotypes planted at three different dates in 1997 and 1998.

\section{Material and Methods}

The plant material in these studies consisted of three black-seeded (Neb-T-4, Neb-T-8, and Neb-T-15), three tan-seeded (Neb-T-3, NebT-5, and Neb-T-14), and two white-seeded (Neb-T-9 and Neb-T-11) tepary bean genotypes. These eight genotypes were planted on three dates each in 1997 (May 29, June 19, and July 10) and 1998 (May 30, June 22, and July 10) at Randolph Farm of Virginia State University, located in Ettrick, Va. (37 ${ }^{0}-15^{\prime} \mathrm{N}$ and $\left.077^{\circ}-30.8^{\prime} \mathrm{W}\right)$. Each experiment consisted of three replicates per planting date (randomized complete block design). Limited quantities of seed necessitated the use of single rows in 1997 when we used a breeding line of soybean [Glycine max (L.) Merr.], similar in height and size to tepary bean, to plant guard rows with each tepary bean row to avoid border effects. However, during 1998, all plots consisted of three rows. The rows were 6-m long with between row spacing of $75 \mathrm{~cm}$. About 200 seeds, without any seed treatment, were planted in each row with a cone-type planter at a depth of $\approx 2.5 \mathrm{~cm}$. These plots received no fertilizer or irrigation applications. The soil for these plots was kept fallow during the previous fall season.
Overall analysis of variance (Table 1) indicated that significant year $\times$ planting date interaction existed for concentrations of protein, calcium $(\mathrm{Ca})$, magnesium $(\mathrm{Mg})$, manganese $(\mathrm{Mn})$, phosphorus $(\mathrm{P})$, and zinc (Zn) whereas significant year $\times$ genotype interaction existed for concentrations of protein and potassium $(\mathrm{K})$. The genotype $\times$ planting date interactions were non-significant for any trait under consideration. It was not possible to evaluate 3-way or higher interactions because seeds from all replications within a planting date were bulked before chemical analyses. Due to the significance of year $\times$ planting date and year $\times$ genotype for many traits, all data were analyzed separately for each year and the results are reported by years (Tables 2 and 3 ).

Planting date affected concentrations of protein, $\mathrm{Ca}$, and $\mathrm{Zn}$ during both years (Tables 2 and 3 ). Results indicated that later planting dates resulted in higher protein concentrations. During 1997, seed produced by plantings done in mid-June and mid-July had significantly higher protein concentration $(+27.7 \%)$ over that produced by planting done in late-May. During 1998 , protein concentration in planting done in mid-July was significantly higher $(+14.3$ and $+13.7 \%$, respectively) than that for plantings done in late-May or mid-June. Both late-May and mid-June plantings during 1998 resulted in similar protein concentrations. Ca concentrations, during both years, were highest in the earliest planting done in late-May as compared to the later planting done in mid-July. Later plantings resulted in increased concentrations of $\mathrm{Zn}$ during both years.

The concentrations of $\mathrm{Mn}$ and $\mathrm{P}$ were affected by planting dates only during 1997. Later plantings resulted in increased concentrations of Mn: the concentration in mid-July planting 
Table 1. Analysis of variance (mean squares) for seed composition traits ${ }^{\mathrm{z}}$ of eight tepary bean genotypes planted at three dates at Ettrick, Va., during 1997 and 1998.

\begin{tabular}{|c|c|c|c|c|c|c|c|c|}
\hline Trait & $\mathrm{Y}^{\mathrm{z}}$ & PD & G & $\mathrm{Y} \times \mathrm{PD}$ & $Y \times G$ & $\mathrm{PD} \times \mathrm{G}$ & $R^{2}$ & $\mathrm{CV}(\%)$ \\
\hline$\overline{\text { Protein (\%) }}$ & $330.1^{* *}$ & $84.3^{* *}$ & $1.6^{*}$ & $36.5^{* *}$ & $1.4^{*}$ & 1.1 & 99.0 & 2.8 \\
\hline B & $0.4^{* *}$ & $0.1^{*}$ & 0.0 & 0.0 & 0.0 & 0.0 & 87.0 & 7.8 \\
\hline $\mathrm{Ca}$ & 208.3 & $8202.1^{* *}$ & 976.2 & $3164.6^{* *}$ & 446.4 & 673.5 & 87.9 & 11.1 \\
\hline $\mathrm{Fe}$ & $96.3^{* *}$ & 16.0 & 10.4 & 12.7 & 9.4 & 9.3 & 77.7 & 27.6 \\
\hline $\mathrm{K}$ & $325052.1^{* *}$ & 11408.3 & $14568.8^{*}$ & 3658.3 & $11528.3^{*}$ & 7675.0 & 92.2 & 4.1 \\
\hline $\mathrm{Mg}$ & $7252.1^{* *}$ & 175.0 & $349.7^{*}$ & $433.3^{*}$ & 80.7 & 91.7 & 91.6 & 4.8 \\
\hline S & $33075.0^{* *}$ & $1731.3^{*}$ & $2379.8^{* * *}$ & 118.8 & 141.7 & 607.4 & 93.7 & 5.6 \\
\hline $\mathrm{Zn}$ & 8.6 & $1.1^{* *}$ & 0.1 & $0.2 *$ & 0.0 & 0.1 & 96.5 & 4.2 \\
\hline
\end{tabular}

${ }^{\mathrm{z}} \mathrm{Y}=$ years, $\mathrm{PD}=$ planting date, and $\mathrm{G}=$ genotypes.

${ }^{*}, *$ Significant at $5 \%$ and $1 \%$ level, respectively.

Table 3. Protein and mineral concentration in seed of eight tepary bean genotypes planted at three dates at Ettrick, Va., during 1997.

\begin{tabular}{|c|c|c|c|c|c|c|c|c|c|c|c|}
\hline \multirow{2}{*}{$\begin{array}{l}\text { Planting } \\
\text { date }\end{array}$} & \multirow{2}{*}{$\begin{array}{c}\text { Protein } \\
(\%)\end{array}$} & \multicolumn{10}{|c|}{ Element [mg/100 g (dry wt)] } \\
\hline & & B & $\mathrm{Ca}$ & $\mathrm{Cu}$ & $\mathrm{Fe}$ & $\mathrm{K}$ & $\mathrm{Mg}$ & $\mathrm{Mn}$ & $\mathrm{P}$ & $\mathrm{S}$ & $\mathrm{Zn}$ \\
\hline Late May & 22.4 & 1.4 & 220 & 1.3 & 12.6 & 1618 & 204 & 2.0 & 520 & 232 & 4.4 \\
\hline Mid-June & 28.6 & 1.2 & 165 & 1.2 & 12.8 & 1624 & 201 & 2.8 & 451 & 344 & 5.0 \\
\hline Mid-July & 28.6 & 1.3 & 161 & 1.3 & 10.8 & 1600 & 207 & 3.5 & 454 & 346 & 4.9 \\
\hline $\begin{array}{l}\mathrm{LSD}_{(0.05} \\
\text { Genotype }\end{array}$ & 0.9 & 0.1 & 27 & NS & NS & NS & NS & 0.4 & 32 & NS & 0.3 \\
\hline Neb-T-3 & 27.2 & 1.3 & 217 & 1.2 & 12.5 & 1747 & 213 & 2.8 & 463 & 363 & 5.1 \\
\hline Neb-T-4 & 26.0 & 1.3 & 187 & 1.3 & 11.3 & 1560 & 203 & 2.9 & 457 & 353 & 4.8 \\
\hline Neb-T-5 & 26.9 & 1.2 & 170 & 1.3 & 13.6 & 1637 & 197 & 3.1 & 483 & 340 & 4.8 \\
\hline Neb-T-8 & 26.1 & 1.2 & 183 & 1.2 & 12.5 & 1600 & 203 & 2.7 & 487 & $357^{\circ}$ & 4.5 \\
\hline Neb-T-9 & 27.3 & 1.1 & 160 & 1.3 & 11.9 & 1557 & 203 & 2.9 & 463 & 310 & 4.8 \\
\hline Neb-T-11 & 25.4 & 1.3 & 190 & 1.4 & 11.5 & 1647 & 210 & 2.8 & 477 & 330 & 4.6 \\
\hline Neb-T-14 & 27.5 & 1.4 & 173 & 1.2 & 10.5 & 1460 & 187 & 2.7 & 460 & 313 & 4.7 \\
\hline Neb-T-15 & 25.7 & 1.2 & 177 & 1.3 & 12.9 & 1703 & 217 & 2.2 & 510 & 333 & 4.7 \\
\hline $\operatorname{LSD}_{(0.05)}$ & NS & NS & NS & NS & NS & 154 & NS & NS & NS & NS & NS \\
\hline
\end{tabular}

Table 3. Protein and mineral concentration in seed of eight tepary bean genotypes planted at three dates at Ettrick, Va., during 1998.

\begin{tabular}{|c|c|c|c|c|c|c|c|c|c|c|c|}
\hline \multirow{2}{*}{$\begin{array}{l}\text { Planting } \\
\text { date }\end{array}$} & \multirow{2}{*}{$\begin{array}{c}\text { Protein } \\
(\%)\end{array}$} & \multicolumn{10}{|c|}{ Element [mg/100 g (dry wt)] } \\
\hline & & B & $\mathrm{Ca}$ & $\mathrm{Cu}$ & $\mathrm{Fe}$ & $\mathrm{K}$ & $\mathrm{Mg}$ & Mn & $\mathrm{P}$ & $\mathrm{S}$ & $\mathrm{Zn}$ \\
\hline Late May & 20.3 & 1.1 & 196 & 1.3 & 7.8 & 1476 & 188 & 3.1 & 436 & 276 & 3.7 \\
\hline Mid-June & 20.4 & 1.1 & 198 & 1.1 & 10.8 & 1470 & 180 & 2.5 & 425 & 288 & 3.9 \\
\hline Mid-July & 23.2 & 1.0 & 165 & 1.2 & 9.2 & 1401 & 171 & 3.0 & 420 & 291 & 4.1 \\
\hline $\mathrm{LSD}_{(0.05)}$ & 1.0 & NS & 23 & NS & NS & NS & 7 & NS & NS & 11 & 0.1 \\
\hline \multicolumn{12}{|l|}{ Genotype } \\
\hline Neb-T-3 & 21.2 & 1.1 & 200 & 1.4 & 13.0 & 1437 & 177 & 2.7 & 433 & 327 & 4.1 \\
\hline Neb-T-4 & 21.0 & 1.1 & 193 & 1.2 & 6.4 & 1457 & 187 & 2.5 & 410 & 290 & 3.8 \\
\hline Neb-T-5 & 21.9 & 1.1 & 173 & 1.1 & 7.0 & 1440 & 180 & 2.9 & 420 & 273 & 3.7 \\
\hline Neb-T-8 & 21.9 & 1.0 & 177 & 1.2 & 7.8 & 1460 & 180 & 2.9 & 443 & 303 & 3.9 \\
\hline Neb-T-9 & 20.5 & 1.0 & 200 & 1.2 & 9.7 & 1463 & 183 & 2.6 & 413 & 263 & 3.9 \\
\hline Neb-T-11 & 20.4 & 1.1 & 200 & 1.2 & 7.9 & 1423 & 183 & 2.8 & 407 & 273 & 3.8 \\
\hline Neb-T-14 & 21.5 & 1.1 & 180 & 1.0 & 10.2 & 1423 & 163 & 3.1 & 420 & 267 & 3.8 \\
\hline Neb-T-15 & 21.8 & 1.1 & 167 & 1.2 & 11.9 & 1490 & 183 & 3.4 & 470 & 283 & 4.0 \\
\hline $\operatorname{LSD}_{(0.05)}$ & NS & NS & NS & NS & NS & NS & 11 & NS & NS & 18 & NS \\
\hline
\end{tabular}

was $25 \%$ higher than that in mid-June planting and the concentration in mid-June planting was $40 \%$ higher than that in late-May planting (Table 2). $\mathrm{P}$ concentration was reduced $13.3 \%$ and $12.7 \%$ by later plantings done in mid-June or mid-July, respectively over the late-May planting. Concentration of $\mathrm{Mg}$ was reduced by later plantings in 1998 only when mid-July planting had the lowest concentration as compared to the other two plantings (Table 3). Sulfur (S) concentrations were increased by later plantings in 1998 when mid-June and midJuly plantings resulted in significantly higher concentrations over late-May planting. These results indicate that, in general, later plantings resulted in higher concentrations of protein, $\mathrm{Mn}, \mathrm{S}$, and Zn, thus, superior nutritional quality. This observation may be of significance given that later tepary bean plantings would afford extra time for farmers interested in planting tepary bean in rotation with winter wheat. We had previously observed that planting dates significantly affected seed yield (Bhardwaj et al., 2002). The highest seed yield (2239 $\mathrm{kg} \cdot \mathrm{ha}^{-1}$ ) was obtained from the late-May plantings. However, yields from mid-June (1899 $\left.\mathrm{kg} \cdot \mathrm{ha}^{-1}\right)$ or early-July $\left(1310 \mathrm{~kg} \cdot \mathrm{ha}^{-1}\right)$ plantings were observed to be acceptable indicating that tepary bean can be produced in rotation with winter wheat in Virginia and probably other southeastern states.

In general, variation among tepary bean genotypes for seed composition traits was not significant (Tables 2 and 3). There was no relationship between seedcoat color and protein or mineral concentrations in tepary bean. During 1997, significant variation existed among eight genotypes only for $\mathrm{K}$ when the concentrations varied from 1460 (Neb-T-14) to 1747 (Neb-T-3) mg/100 g. During 1998, the genotypes differed significantly only for $\mathrm{Mg}$ and $\mathrm{S}$. Highest $\mathrm{Mg}$ concentration was observed in Neb-T-4 and the lowest concentration was observed in Neb-T-14 whereas the highest S concentration was observed in Neb-T-3 and the lowest concentration was observed in Neb-T-9. With regards to $\mathrm{S}$ concentration, Neb-T-14 had the second lowest concentration $(267 \mathrm{mg} / 100 \mathrm{~g})$ which was similar to that of Neb-T-9 $(263 \mathrm{mg} / 100 \mathrm{~g})$. We realize that these studies consisted of a limited number of lines, and evaluations based on a larger group of genotypes may lead to different conclusions. Debouck (1991) reported that worldwide tepary bean repositories consist of 163 cultivated and 156 wild accessions. A next logical step in efforts to characterize tepary bean germplasm for concentrations of protein and minerals might be to evaluate all cultivated and wild accessions. 
Table 4. Means of seed composition traits of eight tepary bean genotypes grown at three planting dates at Ettrick, Va., during 1997 and 1998, compared to the literature values for navy bean, kidney bean, and pinto bean.

\begin{tabular}{|c|c|c|c|c|c|}
\hline \multirow[b]{2}{*}{ Component } & \multicolumn{2}{|c|}{ Tepary Bean } & \multirow{2}{*}{$\begin{array}{l}\text { Navy } \\
\text { bean }^{x}\end{array}$} & \multirow{2}{*}{$\begin{array}{c}\text { Red kidney } \\
\text { bean }\end{array}$} & \multirow{2}{*}{$\begin{array}{l}\text { Pinto } \\
\text { bean }\end{array}$} \\
\hline & VA-grown ${ }^{2}$ & Literature $^{y}$ & & & \\
\hline$\overline{\text { Protein }(\%)}$ & $23.9(19.2-30.6)$ & $13.0-32.2$ & 22.3 & 22.5 & 20.9 \\
\hline \multicolumn{6}{|c|}{ Element $(\mathrm{mg} / 100 \mathrm{~g})$} \\
\hline B & $1.2(1.0-1.5)$ & --- & --- & --- & --- \\
\hline $\mathrm{Ca}$ & $184.2(110.0-260.0)$ & $126-446$ & 155.0 & 83.0 & 121.0 \\
\hline $\mathrm{Cu}$ & $1.2(1.0-2.0)$ & $0.6-3.7$ & 0.9 & 0.7 & 0.8 \\
\hline $\mathrm{Fe}$ & $10.7(5.1-20.6)$ & $0.2-12.6$ & 6.4 & 6.7 & 5.9 \\
\hline $\mathrm{K}$ & $1531.0(1320-1830)$ & $1501-1608$ & 1140.0 & 1359.0 & 1328.0 \\
\hline $\mathrm{Mg}$ & $191.9(160.0-230.0)$ & 95-281 & 173.0 & 138.0 & 159.0 \\
\hline $\mathrm{Mn}$ & $2.8(1.9-4.4)$ & $0.9-3.7$ & 1.3 & 1.1 & 1.1 \\
\hline $\mathrm{P}$ & $451.0(370.0-560.0)$ & $60-432$ & 443.0 & 406.0 & 418.0 \\
\hline $\mathrm{S}$ & $311.3(260.0-410.0)$ & --- & --- & --- & --- \\
\hline $\mathrm{Zn}$ & $4.3(3.5-5.5)$ & $1.7-6.1$ & 2.5 & 2.8 & 2.5 \\
\hline
\end{tabular}

${ }^{\mathrm{z}}$ Grown in Virginia during 1997 and 1998; means over 48 observations: eight genotypes, 2 years, and three planting dates (ranges in parenthesis).

yAdapted from Scheerens et al., 1983.

${ }^{x}$ U.S. Department of Agriculture, Agricultural Research Service. 2002. USDA National Nutrient Database for Standard Reference, Release 15. Nutrient Data Laboratory Home Page.

The concentrations of protein and minerals in tepary bean seeds in our studies were similar to those produced in southwestern U.S., the traditional home of tepary beans (Table 4). The comparisons of tepary bean seeds to those with navy, red kidney, and pinto bean, indicated that tepary bean were nutritionally superior than these edible beans. Information regarding concentrations of $\mathrm{B}$ and $\mathrm{S}$ for tepary beans produced in southwestern U.S. or for navy, red kidney, and pinto bean was not available for comparison. Based on these observations, tepary bean could be useful as a food/feed crop.

The higher $\mathrm{Fe}$ concentration in tepary bean seeds, as compared to navy, red kidney, and pinto bean, can be useful in alleviating worldwide deficits of this mineral. It has been estimated that $\approx 30 \%$ of world population suffers from Fe deficiency (WHO, 1992) making the $\mathrm{Fe}$ deficiency most widespread in the world. Lucca et al. (2002) suggested that grains combining higher Fe concentration with phytase and cysteine-peptide have great potential to substantially improve iron nutrition. The cultivated tepary bean, a short lifecycle annual desert legume, indigenous to northwestern Mexico and the southwestern U.S. (Nabhan, 1983), is similar to dry bean (Phaseolus vulgaris L.). Tepary bean is known to be highly tolerant to heat and drought stress. The seeds of tepary bean are nutritious, contain high protein, and are suitable for human consumption (Miklas et al., 1994; Thomas et al., 1983). Due to these attributes, tepary bean, could be suitable for commercial production, as a food grain, in parts of the world where droughts are common, such as Africa.

\section{Literature Cited}

Association of Official Analytical Chemists. 1995. Official methods of analysis. $16^{\text {th }}$ ed. Assn. Official Anal. Chem., Arlington, Va..

Bhardwaj, H.L., M. Rangappa, and A.A. Hamama. 2002. Planting date and genotype effects on tepary bean productivity. HortScience 37(2):317-318.

Blade, S.F. and A.E. Slinkard. 2002. New crop development: The Canadian experience, p. 62-75. In: J. Janick and A. Whipkey (eds.). Trends in new crops and new uses. ASHS Press, Alex., Va.

Debouck, D.G. 1991. Diversity in Phaseolus species in relation to the common bean, p. 25-52. In: S.P. Singh (ed.). Common bean improvement in the twenty-first century. Kluwer, Dordrecht, Netherlands.

Fletcher, R.J. 2002. International new crop developmentincentives, barriers, processes, andprogress: An Australian experience, p. 40-54. In: J. Janick and A. Whipkey (eds.). Trends in new crops and new uses. ASHS Press, Alex., Va.

Lucca, P., R. Hurrell, and I. Potrykus. 2002. Fighting iron deficiency anemia with iron-rich rice.J. Amer. College Nutr. 21(3):184S-190S.

Miklas, P.N., J.C. Rosas, J.S. Beaver, L. Telek, and G.P.Freytag. 1994. Field performance ofselected tepary bean germplasm in the tropics. Crop Sci. 34:1639-1644.

Nabhan, G.P. 1983. The desert tepary as a food source. In: F.S. Crosswhite (ed.). Desert plants. vol. 5. no. 1. Univ. Ariz. Boyce Thompson S.W. Arboretum, Superior.

SAS Institute. 1996. SAS System for Windows. SAS Inst., Inc., Cary, N.C.

Scheerens, J.C., A.M. Tinsley, I.R. Abbas, C.W. Weber, and J.W. Berry. 1983. The nutritionalsignificance of tepary bean consumption. In: F.S. Crosswhite (ed.). Desert plants. vol. 5, no. 1. Univ. Ariz. Boyce Thompson S.W.Arboretum, Superior.

Steel, R.G.D. and J.H. Torrie. 1980. Principles and procedures of statistics, A biometrical approach. McGraw-Hill Book Company, New York.

Thomas, C.V., R.M. Manshardt, and J.G. Waines. 1983. Teparies as a source of useful traits for improving common beans, p. 43-48. In: F.S. Crosswhite (ed.). Desert plants. vol. 5, no. 1. Univ. Ariz. Boyce Thompson S.W. Arboretum, Superior.

U.S. Department of Agriculture. 2002. Nutrient database for standard reference. release 15 . 17 Dec. 2003. http://www.nal.usda.gov/fnic/ foodcomp/.

World Health Organization. 2002. National strategies for overcoming micronutrient malnutrition. Doc. A45/3. WHO, Geneva. 